\title{
FLAVONOIDS OF THE BARK OF SALIX ELBURSENSIS
}

\section{A. Kompantsev}

Khimiya Prirodnykh Soedinenii, Vol. 5, No. 4, pp. 323-324, 1969

The flavonoids of the leaves of Salix purpurea L. (purpleosier willow) [1], which, according to A. K. Skvortsov, must be regarded as Salix elbursensis Boiss $[2,3]$, have been studied previously. The latter is endemic to the region of the Caucasus and Iran and belongs to the section Purpuraea $\mathrm{L}$.

The dried comminuted bark $(1.5 \mathrm{~kg}$ ) from branches of 1 to 5 years' growth was exhaustively extracted with $70 \%$ ethanol. The ethanolic extract was concentrated in vacuum, diluted with water and treated first with chloroform and then with ethyl acetate. The ethyl acetate extract was evaporated to small bulk, and the flavonoids were precipitated by means of dry chloroform. The deposit that separated was dissolved in the minimum amount of 50\% ethanol, and diethyl ether was added to saturation. The mixture was left in the refrigerator at $3-4^{\circ} \mathrm{C}$. After $10-12$ days, $5,7,4^{*}$-trihydroxyflavone 5- $\beta$-D-glucopyranoside (salipurposide) [4], $\mathrm{C}_{21} \mathrm{H}_{22} \mathrm{O}_{10} \cdot 1.5 \mathrm{H}_{2} \mathrm{O}$, with mp $226-227^{\circ} \mathrm{C}$ (water), $\lambda_{\max } 328,282 \mathrm{~m} \mu$ crystallized out; melting point of the acetyl derivative $182-183^{\circ} \mathrm{C}(96 \%$ ethanol).

The cambial layer was separated from the bark $(0.8 \mathrm{~kg})$ of growth more than 50 years old in the form of a lemon yellow strip, and it was dried, comminuted, and extracted in a Soxhlet apparatus with diethyl ether saturated with water. The extract was concentrated to $1 / 2$ of its initial volume and was placed in a refrigerator at $3-4^{\circ} \mathrm{C}$.

The precipitate that deposited after a day was washed with dry ether and dissolved in the minimum amount of anhydrous acetone, and the solution was filtered. The filtrate was brought to the boil and 2 to 3 volumes of hot water was added. On cooling, the mixture deposited bright orange crystals of $4,2^{*}, 4^{*}, 6^{*}$-tetrahydroxychalcone $6^{*}$ - $B$-D-glycopuranoside (isosalipurposide) [5], $\mathrm{C}_{21} \mathrm{H}_{22} \mathrm{O}_{10} \cdot 2 \mathrm{H}_{2} \mathrm{O}, \operatorname{mp} 171-173^{\circ} \mathrm{C}$ (water), $\lambda_{\max } 368 \mathrm{~m} \mu$.

\section{REFERENCES}

1. V. A. Kompantsev and A. L. Shinkarenko, KhPS [Chemistry of Natural Compounds], 4, 380, 1968.

2. E. Boissier, Flora Orientalis, 4, Genevae et Basileae, 1879.

3. A. K. Skvortsov, Novosti syst. vyssh. rast., 58, 1966.

4. C. Charax and I. Rabate, Compt. rend. Acad. Sciences, 192, 1478-1480, 1931.

5. C. Charax and I. Rabate, Compt. rend. Acad. Sciences, 196, 816-818, 1933.

13 March $1969 \quad$ Pyatigorsk Pharmaceutical Institute

UDC 547.972

\section{FLAVONOIDS OF CENTAUREA DEPRESSA}

V. A. Bandyukova, Kh. Kh. Khalmatov, and Kh. I, Alimov

Khimiya Prirodynkh Soedinenii, Vol. 5, No. 4, pp. 324-325, 1969

From the flowerheads of Centaurea depressa $\mathrm{M}$. B. growing in Uzbekhistan we extracted the combined flavonoids with $96 \%$ ethanol. Paper chromatography established the presence in the extract of six flavone and flavonol compounds [1].

Hydrolysis of the substances isolated from the acidic aqueous fraction gave an aglycone with the composition $\mathrm{C}_{15} \mathrm{H}_{10} \mathrm{O}_{5}, \mathrm{mp} 340^{\circ} \mathrm{C}$, which was identified on the basis of its acetate with mp $236-237^{\circ} \mathrm{C}$ and the products of alkaline fusion as scutellarein. The carbohydrate part of the glycosides consisted of B-D-glucuronic acid.

Two glycosides were isolated from the same fraction. One with the composition $\mathrm{C}_{21} \mathrm{H}_{18} \mathrm{O}_{12}$ had no sharp melting point. On the basis of spectral analyses and the bathochromic shift we identified it as scutellarein 7-B-D-glucuronoside. The second glycoside of this fraction was similar in properties to that described above and is, apparentiy, scutellarein $5-\beta-D$-glucuronoside.

From the ethyl acetate fraction we isolated a substance with the composition $\mathrm{C}_{21} \mathrm{H}_{20} \mathrm{O}_{12} \cdot \mathrm{H}_{2} \mathrm{O}$, mp $220-222^{\circ} \mathrm{C}$

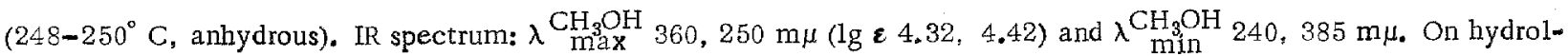
ysis it yielded quercetin with $\mathrm{mp} 305^{\circ} \mathrm{C}$ and $\mathrm{D}$-glucose in a molar ratio of $1: 1$. The glycoside was readily hydrolyzed 